\title{
MELANOMA: RIZIKOS VEIKSNIAI IR PREVENCINĖS PRIEMONĖS
}

\author{
Živilė Aukštakojytė ${ }^{1}$, Aistė Pociūtè ${ }^{1}$, Viktorija Trinkūniene் ${ }^{2}$ \\ ${ }^{1}$ Lietuvos sveikatos mokslu universiteto Medicinos akademija, Medicinos fakultetas, \\ ${ }^{2} V$ Ss I Ukmergès ligoninès Dermatovenerologijos konsultaciju poliklinika
}

Raktažodžiai: melanoma, UVA (ultravioletinių spindulių A), UVB (ultravioletinių spindulių B), odos vėžys.

\section{Santrauka}

Melanoma - vienas agresyviausių piktybinių navikų, linkęs greitai metastazuoti i sritinius limfmazgius, vidaus organus ir dažnai, ypač, jeigu laiku nebuvo pradètas gydymas, baigiasi mirtimi. Lietuvoje 2019 metais sergančiujų melanoma skaičius buvo 2128. Siekiant užkirsti kelią naujiems šio onkologinio susirgimo atvejams, būtina aktyviai informuoti visuomenę apie melanomos rizikos veiksnius ir būdus, padedančius sumažinti šio onkologinio susirgimo grèsmę. Darbo tikslas - išsiaiškinti naujausius duomenis apie melanomos rizikos veiksnius ir jos prevencijos priemones.

Tyrimo medžiaga ir metodai. Mokslinėse duomenu bazèse rastos publikacijos. Literatūros paieška atlikta PubMed ir Google Scholar duomenų bazèse. Literatūros paieškai buvo naudojami raktiniai žodžiai, kurie atitiko apžvalgos temą. Apžvalgai buvo naudojami ne senesni nei 5 metu literatūros šaltiniai.

Rezultatai. Melanomos rizikos veiksniai yra UVA ir UVB spinduliuote, genetinès priežastys (teigiama šeiminè melanomos anamnezè, naujos mutacijos), fenotipiniai požymiai (raudoni plaukai ar labai šviesi odos spalva), daugybiniai ir atipiški apgamai. Didesnè melanomos rizika susijusi su imunosupresinėmis būklëmis ir vyresniu amžiumi (asmenys $>50$ metų). Norint sumažinti melanomos riziką, būtina vengti nudegimo saulèje, nesinaudoti dirbtinio ịdegio įrenginiais. Rekomenduojama naudoti priemones, padedančias apsisaugoti nuo žalingo ultravioletinès spinduliuotès poveikio: apsauginius kremus su SPF filtru, skrybèles plačiais kraštais, akinius nuo saulès. Jeigu ìmanoma, vengti buvimo lauke tomis valandomis, kai saulè kaitriausia. Svarbu nuolat stebėti, ar neatsiranda naujų apgamų, ịvertinti senų apgamų pokyčius ir bendrają odos būklę. Pastebejjus odos pakitimų, nedelsiant kreiptis ị šeimos gydytoją, kuris turètų atlikti pirminę odos apžiūrą, o esant pigmentinių pakitimų, kuo greičiau siųstų gydytojo dermatovenerologo konsultacijai.

Išvados. Didžiausi melanomos rizikos veiksniai yra UVA ir UVB spinduliuotè, tačiau melanomos išsivystymas gali būti susijęs ir su genetine predispozicija, fenotipiniais požymiais, imunosupresinėmis būklèmis. Visuomenès švietimas reikalingas ugdyti gyventojų melanomos rizikos supratimą. Siekdami sumažinti melanomos išsivystymo riziką, pirminès sveikatos priežiūros specialistai turi būti budrūs, o visuomenè sąmoningai naudoti apsaugines priemones nuo ultravioletinès spinduliuotès.

\section{Ivadas}

Melanoma - vienas agresyviausių piktybinių navikų. Odos melanoma kilusi iš nekontroliuojamai proliferuojančių pigmentinių ląstelių (melanocitų), esančių epidermyje. Dèl šios priežasties melanoma dažniausiai atsiranda odoje, tačiau gali formuotis ir kitose kūno srityse: gleivinèse, naguose, akyse (junginèje, stiklakūnyje), smegenų dangaluose. Navikas linkęs greitai metastazuoti ị sritinius limfmazgius ir vidaus organus, todèl ankstyva diagnostika ir laiku pradètas gydymas gali pagerinti išgyvenamumą. Nustačius I stadijos melanomą ir laiku pradejus gydymą, prognozè santykinai gera - išgyvenamumas siekia 95-98 procentus [1].

Žinoma nemažai melanomos rizikos veiksnių: fenotipas, teigiama šeiminè melanomos anamnezè, didelis apgamų skaičius, tačiau įrodyta, kad pagrindinis rizikos veiksnys yra ultravioletinè (toliau - UV) saulès spinduliuotè. Ultravioletinių spindulių A (bangos ilgis - 315-400 nm) ir ultravioletinių spindulių B (bangos ilgis - 280-315 nm) kumuliacinis poveikis sukelia DNR pažeidimą, oksidacinį stresą bei odos uždegimą, kas skatina nekontroliuojamą melanocitų proliferaciją [2].

Nors visuomené nuolat informuojama apie žalingą saulès 
spinduliuotès poveikị žmogaus organizmui, sergamumo melanoma ir mirtingumo skaičiai yra gana aukšti. 2015 metais visame pasaulyje diagnozuota 351,880 naujų melanomos atvejų, iš kurių 59,782 baigèsi mirtimi [3]. Lietuvoje 2019 metais melanoma sirgo 2128 asmenų [4]. Siekiant užkirsti kelią šio onkologinio susirgimo išsivystymui ir sumažinti mirčių nuo jo skaičių, būtina aktyviai informuoti visuomenę apie melanomos grèsmę ir būdus, padèsiančius sumažinti susirgimo riziką.

Darbo tikslas - apžvelgti naujausius duomenis apie melanomos rizikos veiksnius ir jos prevencijos priemones.

\section{Tyrimo medžiaga ir metodai}

Nagrinètos mokslinėse duomenų bazèse rastos publikacijos pasirinkta tema. Literatūros paieška atlikta PubMed ir Google Scholar duomenų bazèse. Literatūros paieškai buvo naudojami raktiniai žodžiai, atitinkantys apžvalgos temą. Analizuoti ne senesni nei 5 metų literatūros šaltiniai.

\section{Tyrimo rezultatai ir jų aptarimas \\ Melanomos rizikos veiksniai}

Ultravioletinių spindulių poveikis. Saulè skleidžia ultravioletinę spinduliuotę (UVA ir UVB), nuo kurios Žemę saugo ozono sluoksnis. Jis neleidžia prasiskverbti ypač kenksmingai UV spinduliuotei, sudarydamas sąlygas Žemę pasiekti tik žemos energijos UVA ir UVB spinduliams. İrodyta, jog UV spinduliuote be išimčių gali būti kenksminga visiems gyviems organizmas. Ji sukelia odos pakitimus: eritemą, fotoaktyvumą. Svarbiausia, jog ultravioletinès spinduliuotés veikimas sukelia mutacijas, kurios yra tiesiogiai siejamos su melanominès ir nemelanominès kilmès odos navikų išsivys-

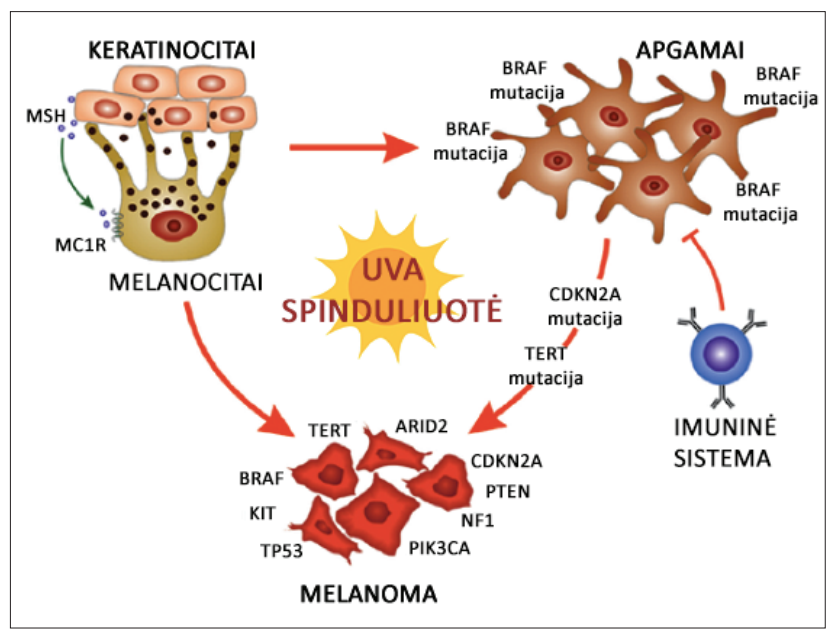

1 pav. Melanomos onkogenezès procesas, veikiant UVA spinduliuotei [9] tymu (1 pav.) [5,6]. Veikiant UVA spinduliams, melanocitai gali tiesiogiai transformuotis i neoplastines ląsteles arba ị gerybinius apgamus, kurie 80 proc. atvejų turi B-Raf protoonkogeno (toliau - BRAF) mutaciją [9]. Šie apgamai gali ilgai išlikti nepakitę, tačiau UVA spindulių veikimas gali paskatinti papildomų mutacijų (TERT, CDKN2A) atsiradimą ir melanomos išsivystymą [9]. UV spinduliuotè gali sukelti mutacijas tiesiogiai veikdama ląstelès DNR, arba netiesiogiai, skatindama reaktyviujų deguonies rūšiu (toliau - ROS) susidarymą [7]. Ištirta, jog vienas ar daugiau stiprių nudegimų nuo saulès vaikystėje lemia du kartus didesnę melanomos išsivystymo riziką vyresniame amžiuje [8].

Melanomos vystymuisi daugiausiai reikšmès turi protarpinè saulès ekspozicija (ypač eriteminès saulès dozès). Tuo tarpu nuolatinè (lètinè) saulès ekspozicija yra labiau susijusi su aktininių keratozių ir nemelanominio odos vėžio išprovokavimu [5]. Vadinasi, rizikos grupèms priklauso tie asmenys, kurie neišvengiamai patiria ilgalaikę saulès ekspoziciją: dirbantys lauke, sportuojantys atvirose saulei vietose (lauko tenisas, futbolas, krepšinis). Svarbu nepamiršti ir to, jog dirbtinès UV apšvitos metu (pavyzdžiui, deginantis soliariume) gaunamas ultravioletinès spinduliuotès kiekis gali būti netgi didesnis nei lauke, ar ilgą laiką deginantis saulèje. Irodyta, jog melanomos rizika 15 proc. padideja asmenims, kurie bent kartą gyvenime deginosi dirbtinio įdegio kabinose, lyginant su tais, kurie niekada nesidegino [8]. Naujausi tyrimai rodo, jog toks deginimosi būdas neimanomas be DNR pažeidimo, kuris didina melanomos išsivystymo riziką [8].

Vidiniai organizmo veiksniai (genetinė predispozicija). Be išorinių aplinkos veiksnių, tokių, kaip UV spinduliuote, melanomos išsivystymo riziką gali nulemti ir vidiniai (igimti) organizmo veiksniai. Teigiama šeiminè melanomos anamnezè susijusi su 7-15 proc. melanomos atvejų [9]. Nustatyta, kad melanomos atsiranda šeimose, kurios linkusios ị specifinius piktybinių navikų modelius: B-K apgamų sindromas (pavadintas pagal pirmujų pacientų vardų pirmąsias raides) arba autosominiu dominantiniu būdu paveldima genodermatozè, melanomos-astrocitomos sindromas [9]. Tokioms šeimoms dažniausiai nustatomos nuo ciklino priklausomo kinazès inhibitoriaus 2A (CDKN2A) ir nuo ciklino priklausomos kinazès 4 (CDK4) genų mutacijos [9]. Manoma, kad su didesne melanomos išsivystymo rizika susijusios ir šios paveldimos būklès: pigmentinè kseroderma, šeiminè retinoblastoma, Lynčo ir Li-Fraumeni sindromai [9]. Melanomos išsivystymo riziką didina šie onkogenai: BRAF, neurofibromino 1 (NF1) ir NRAS mutacijos. Nustatyta, kad lètinis saulès poveikis odai nulemia šių genų mutacijas ir skatina melanomos vystymąsi [10].

Fenotipiniai ypatumai. Melanomos rizikos veiksniais laikomi ir tam tikri žmogaus fenotipo bruožai. Asmenys, 
kurių iš prigimties rausvi plaukai, šviesi odos spalva, šviesios akys (atitinkantys I-II fototipą pagal Fitzpatrick odos tipų klasifikacijos skalę), maža odos pigmentacija, yra jautresni UV spinduliams, todèl jiems didesné piktybinių odos navikų išsivystymo rizika [9].

Didelis apgamų kiekis ir atipiniai apgamai. Daugiau nei 100 apgamų visame kūne, ar daugiau nei 11 ant rankos, didesni nei $5 \mathrm{~mm}$ apgamai, ypač gigantiniai ( $>20 \mathrm{~cm}$ dydžio) susiję su didesne melanomos išsivystymo rizika [11]. M. Arumi-Uria ir bendraautoriai nustate, jog rizika susirgti melanoma susijusi su displazinių apgamų atipijos laipsniu ląstelèse. Esant ryškiai atipijai, rizika susirgti melanoma yra didesnè (19,7 proc.), lyginant su vidutine ir lengva atipijomis [12].

Imunosupresiški pacientai. Naujai atsiradusi melanoma dažniau diagnozuojama pacientams, kurių nusilpęs imunitetas: sergantiems lètinèmis ligomis, vartojantiems imunosupresinius vaistus.

Amžius. Odos vèžio paplitimas didèja su amžiumi, nes senstant mažèja odos gebejjimas regeneruotis po žalingo ultravioletinès spinduliuotés poveikio [13]. İdomu, jog apie pusė visų melanomos atvejų nustatoma jaunesniems nei 50 metų žmonèms. Remiantis literatūros duomenimis, melanoma yra dažniausiai nustatomas navikas 25-29 metu pacientams ir trečias navikas pagal dažnumą 20-24 metų amžiaus grupèje [14].

Melanomos prevencinès priemonès. Visuomenès mokymas yra pati ankstyviausia melanomos prevencijos priemonè. Kad sergamumas melanoma mažetų, svarbu, jog visuomené būtų pakankamai informuota apie melanomą sukeliančius rizikos veiksnius ir priemones išvengti šio piktybinio susirgimo. Visuomenès budrumas užkirsti kelią melanomos atsiradimui turi būti ugdomas nuo mažens, todèl vaikų darželiuose ir mokyklose turètų būti kalbama apie UV spindulių neigiamą poveiki žmogaus sveikatai, skatinama naudoti priemones, kurios padètu apsisaugoti nuo žalingos UV spinduliuotès. Tokią prevenciją turètų vykdyti visuomenès sveikatos specialistai, pirminès sveikatos priežiūros grandies medikai.

Daug diskusijų kyla dèl odos véžio prevencinių priemonių programų kūrimo. Šiuo metu Lietuvoje nèra odos véžio prevencijos priemonių programos. Lietuvos sveikatos apsaugos ministerijos darbo grupès, šalies mokslininkai ir gydytojai padarè išvadą, jog tokių prevencinių priemonių efektyvumas nepagrịstas kitų valstybių patirtimi ir geraja praktika, todèl efektyviau būtų organizuoti mokymus apie ankstyvą odos vèžio įtarimą pirminèje sveikatos priežiūros grandyje. Tuo tarpu kitose valstybèse tokios prevencinès programos igyvendinamos. Efektyvių rezultatų pasiekè australai, kai nuo $1988 \mathrm{~m}$. Viktorijos valstijoje įdiegè ap- saugos nuo saulès programą „SunSmart“, kuri palaipsniui buvo igyvendinta visose Australijos valstijose ir teritorijose [15]. ,SunSmart“ bendradarbiauja su pradinèmis ir vidurinėmis mokyklomis, sveikatos priežiūros specialistais, vietos valdžia, siekdami sukurti ir igyvendinti išsamią apsaugos nuo saulès politiką, sumažinti UV spindulių poveikị ir su tuo susijusią onkologinių odos ligų riziką. Praejjus dešimtmečiams pastebèta, kad odos vėžio dažnis tarp paauglių ir jaunesnių žmonių Australijoje pradèjo stabilizuotis arba mažèti $[16,17]$.

Savo odos būklès stebėsena. Visuomenei būtina suprasti, kad svarbu nuolat stebèti savo odos būklę, atkreipiant dèmesị i naujus apgamus ir ị senų apgamų pakitimus. Pastebejjus pokyčius, reikia nedelsiant kreiptis ị šeimos gydytoją.

Laiku atliekama odos apžiūra pirminẻje sveikatos priežiūros grandyje. Didžiają dali piktybinių pakitimų galima anksti diagnozuoti ir laiku pradèti gydymą, užkertant kelią mirtinoms baigtims. Dẻl šios priežasties šeimos gydytojų vaidmuo ypač svarbus, siekiant sumažinti mirtingumą nuo melanomos. Pagerinti ankstyvają melanomos diagnostiką galima tiriant i melanomą panašius pažeidimus pagal ABCDE kriterijus: asimetrija, nelygūs (netaisyklingi) kraštai, nevienoda spalva, $>5 \mathrm{~mm}$ skersmuo, nors literatūroje vis dažniau aprašomi melanomos atvejai, kai apgamo skersmuo nesiekè $5 \mathrm{~mm}$, todèl skersmens kriterijaus reikšmè tampa abejotina ir pastaruoju metu vis dažniau vertinama darinio dinamika [9]. E kriterijus žymi apgamo paviršiaus nelygumus ir (arba) paraudimą aplink jị, keitimąsi laiko atžvilgiu. Kitas dažnai diagnostikoje taikomas terminas yra „bjauriojo ančiuko" požymis: pigmentinis darinys išsiskiria iš kitų apgamų to paties paciento odoje. Svarbu, kad šeimos gydytojas ịvertintų pacientų (ypač rizikos grupių) išorinius (fenotipiniai požymiai, darbas saulèje, polinkis degintis) ir genetinius (teigiama šeiminė anamnezè, sindromai, kuriems būdingas polinkis į melanomos formavimąsi) veiksnius, skirtų daugiau dèmesio kūno odos apžiūrai ir sritinių limfmazgių apčiuopai. Kasmetine patikra rekomenduojama tiems, kurių atipiniai apgamai nekinta, o esant bet kokių pokyčių, dermatoskopija rekomenduojama kas 6 mènesius arba dažniau.

Šeimos gydytojas turètų rekomenduoti apsaugines priemones nuo ultravioletinès spinduliuotès ir patarti, kokias naudoti. Deja, JAV tyrimų rezultatai parodè, kad tik apie trečdalis pirminès sveikatos priežiūros gydytojų pataria pacientams naudoti apsaugines priemones nuo saulès, o pusé - vengti dirbtinių saulès spindulių (soliariumų) [18].

Apsauginės priemonės nuo ultravioletinės spinduliuotès. Apsauginių kremų nuo saulès efektyvumas yra pagristas moksliniais tyrimais. Irodyta, jog tokių priemonių naudojimas gali sumažinti melanomos riziką iki 50 procentų [19]. Apsauginių priemonių nuo saulès veiksmingumą patvirtina Australijos mokslinių tyrimų rezultatai. Vertinant dešimties 
metų laikotarpi nustatyta, kad 5 proc. padidèjus apsauginių kremų nuo saulès naudojimui, naujų melanomos atvejų skaičius sumažèjo 10 procentų [20]. Kiti tyrëjai apsauginių kremų nuo saulès vartojimą vertina prieštaringai [21]. Sisteminès metaanalizès rezultatai parodè, kad kremai nuo saulès gali kliniškai reikšmingai sumažinti vitamino D gamybą, todèl reikia atsižvelgti ne tik ị apsaugos nuo saulès poveikio naudą, bet ir i galimą tokių kremų vartojimo riziką.

Apsauginių kremų nuo saulès pasirinkimas yra platus. Renkantis apsauginį kremą, reikètų atkreipti dèmesị i apsaugos nuo saulès veiksni (toliau - SPF). Šis veiksnys parodo, kiek efektyviai priemonė apsaugo nuo UVB spindulių (labiau susiję su melanomos išsivystymu), o apsaugą nuo UVA spindulių parodo kitas ženklinimas (dažnai žymima pliusu šalia SPF). Kremai su SPF skirstomi pagal tai, kiek jie leidžia prasiskverbti per odą saulès spinduliams. SPF 2 - per odą prasiskverbia $1 \frac{1}{2}$ UVB saulès spindulių (nepraleidžia $50 \%$ UVB spindulių), atitinkamai SPF 15 - 1/15 UVB saulès spindulių (nepraleidžia apie 93\%), SPF 30 - 1/30 UVB saulès spindulių (nepraleidžia apie 97\%), SPF 50 - 1/50 UVB saulès spindulių (nepraleidžia apie 98\%), SPF $100-$ 1/100 UVB saulès spindulių, todèl tokie kremai neleidžia prasiskverbti net 99 proc. UVB spindulių [22]. Labiausiai rekomenduojama rinktis plataus spektro (saugančias nuo UVA ir UVB) priemones, kurių SPF bent 30, pirmenybę teikti vandeniui atsparioms priemonems. Renkantis svarbu atsižvelgti ị odos tipą: gelio konsistencijos priemonès tinka riebiai odai, o sausai geriau naudoti losjonus. Atlikti tyrimai rodo, jog žmonès linkę naudoti per mažą kiekị apsauginio kremo nuo saulès [3], todèl reikètų jo naudoti pakankamai (suaugusiems apie $30 \mathrm{ml}$ ). Būtina ištepti visas atviras kūno vietas, kurias pasiekia saulès spinduliai ir pakartotinai naudoti kremą kas 2 valandas, po maudynių ar suprakaitavus.

Odą nuo kenksmingos saulès spinduliuotès saugantys kremai skirstomi ị grupes pagal juose esančius cheminius arba fizinius filtrus. Cheminiai filtrai absorbuoja UV spindulius. Fiziniai filtrai ị odą ịsigeria prastai ir sudaro apsaugini barjerą. Jie ant odos paviršiaus išlieka ilgai ir atspindi UV spindulius.

Be apsauginių kremų nuo saulès būtina naudoti ir kitas apsaugines priemones. Siekiant išvengti žalingos saulès spinduliuotès, vengti buvimo lauke tomis valandomis, kai saulè kaitriausia (pirmoje dienos pusejje ir pietų metu), rekomenduojama dèvèti skrybėles plačiais kraštais ir akinius nuo saulès.

Mikrobioma - žmogaus organizme gyvenančių mikroorganizmų visuma. Mikrobiomos reikšmè melanomos išsivystymui vis dar yra klinikinių studijų lygmenyje [23]. Tyrejjai siekia išsiaiškinti, ar specifinès žmogaus žarnyno bakterijos susijusios su atsparumu melanomos išsivystymui.
Bandoma išsiaiškinti, ar tam tikros žmogaus žarnyno bakterijų rūšys susijusios su didesniu teigiamu atsaku ị melanomos gydymą [23].

\section{Išvados}

Pirminė melanomos profilaktika pirmiausia turi apimti gyventojų švietimą apie saugų elgesį sauleje ir padarinius sveikatai, kai saugaus elgesio rekomendacijų nepaisoma. Būtina skatinti visuomenę vengti stipraus nudegimo saulèje, nesinaudoti dirbtinio įdegio įrenginiais. Skatinti priemonių, skirtų apsisaugoti nuo ultravioletinès spinduliuotès, naudojimą, vengti buvimo lauke didžiausios kaitros metu, o tokios galimybès nesant - dèvèti skrybèles plačiais kraštais ir akinius nuo saulès. Šeimos gydytojas turètų įvertinti kiekvieno savo paciento melanomos rizikos veiksnius.

Antrinė profilaktika. Svarbu nuolat stebėti, ar odoje neatsirado naujų apgamų ir nepakito senujų spalva, dydis, paviršiaus reljefas. Pastebejus pakitimus, nedelsiant kreiptis ị šeimos gydytoją. Kiekvienas šeimos gydytojas turètų atsakingai atlikti paciento odos apžiūrą, pagal $\mathrm{ABCDE}$ taisykles ìvertinti, ar odos pakitimai nebūdingi piktybinei ligai. Pastebèjęs pigmentinių darinių pakitimus odoje, šeimos gydytojas turètų kuo greičiau siųsti pacientą gydytojo dermatovenerologo konsultacijai.

\section{Literatūra}

1. Singh P, Kim H, Schwartz R. Superficial spreading melanoma. Melanoma Research 2016;26(4):395-400. https://doi.org/10.1097/CMR.0000000000000245

2. Sample A, He Y. Mechanisms and prevention of UV-induced melanoma. Photodermatol Photoimmunol Photomed 2017;34(1):13-24.

https://doi.org/10.1111/phpp.12329

3. Rueegg C, Stenehjem J, Egger M, Ghiasvand R, Cho E, Lund $\mathrm{E}$, et al. Challenges in assessing the sunscreen-melanoma association. Int J Cancer 2019;144(11):2651-2668. https://doi.org/10.1002/ijc.31997

4. Sergančiųjų asmenų skaičius pagal diagnozių grupes. Higienos institutas. https://stat.hi.lt/default.aspx?report_ $\mathrm{id}=168 \&$ fbclid $=$ IwAR3P2Zz3J2rcj8O_uH7hnMB2uD3Oso4c8a18RYfZthG8ZjmMJ9X_COoOg0I

5. Gandini S, Sera F, Cattaruzza MS, Pasquini P, Picconi O, Boyle P, Melchi CF. Meta-analysis of risk factors for cutaneous melanoma: II. Sun exposure. Eur J Cancer 2005;41(1): 45-60. https://doi.org/10.1016/j.ejca.2004.10.016

6. Schuch A, Moreno N, Schuch N, Menck C, Garcia C. Sunlight damage to cellular DNA: focus on oxidatively generated lesions. Free Radical Biology and Medicine 2017;107:110-124. https://doi.org/10.1016/j.freeradbiomed.2017.01.029

7. Bastian BC. The molecular pathology of melanoma: an inte- 
grated taxonomy of melanocytic neoplasia. Annu Rev Pathol 2014;9:239-271.

https://doi.org/10.1146/annurev-pathol-012513-104658

8. Weinstock MA, Colditz GA, Willett WC, et al. Nonfamilial cutaneous melanoma incidence in women associated with sun exposure before 20 years of age. Pediatrics 1989;84:199-204.

9. Leonardi GC, Falzone L, Salemi R, et al. Cutaneous melanoma: from pathogenesis to therapy (Review). Int J Oncol 2018;52(4):1071-1080.

https://doi.org/10.3892/ijo.2018.4287

10. Thomas L, Puig S. Dermoscopy, digital dermoscopy and other diagnostic tools in the early detection of melanoma and follow-up of high-risk skin cancer patients. Acta Derm Venereol 2017; Suppl 218:14-21.

https://doi.org/10.2340/00015555-2719

11. Clinical practice guidelines for the management of melanoma in Australia and New Zealand. www.nhmrc.gov.au

12. Arumi-Uria M, McNutt NS, Finnerty B. Grading of atypia in nevi: correlation with melanoma risk. Mod Pathol 2003;16:764771.

https://doi.org/10.1097/01.MP.0000082394.91761.E5

13. CDC. Guidelines for school programs to prevent skin cancer. MMWR 2002;51(RR04):1-16.

14. Cancer query systems (CanQues). National cancer institute. $\mathrm{http}: / /$ seer.cancer.gov/ScientificSystems/CanQues.

15. SunSmart Victoria. History. 2015. http://www.sunsmart.com. au/about/history.

16. Olsen CM, Williams PF, Whiteman DC. Turning the tide? Changes in treatment rates for keratinocyte cancers in Australia 2000 through 2011. J Am Acad Dermatol 2014;71:21-6.e1. https://doi.org/10.1016/j.jaad.2014.02.011

17. Iannacone MR, Youlden DR, Baade PD, Aitken JF, Green AC. Melanoma incidence trends and survival in adolescents and young adults in Queensland, Australia. Int J Cancer. 2015;136(3):603-9.

https://doi.org/10.1002/ijc.28956

18. Geller AC, O'Riordan DL, Oliveria SA, Valvo S, Teich M, Halpern AC. Overcoming obstacles to skin cancer examinations and prevention counseling for high-risk patients: results of a national survey of primary care physicians. J Am Board Fam Pract 2004;17(6):416-23.

https://doi.org/10.3122/jabfm.17.6.416

19. Merlino G, Herlyn M, Fisher DE, et al. The state of melanoma: challenges and opportunities. Pigment Cell Melanoma Res 2016;29(4):404-416.

https://doi.org/10.1111/pcmr.12475

20. Olsen CM, Wilson LF, Green AC, et al. How many melanomas might be prevented if more people applied sunscreen regularly? Br J Dermatol 2018;178(1):140-147.

https://doi.org/10.1111/bjd.16079
21. Neale RE, Khan SR, Lucas RM, Waterhouse M, Whitemanand $\mathrm{DC}$, Olsen CM. The effect of sunscreen on vitamin D: a review. Br J Dermatol 2019;181(5):907-915.

https://doi.org/10.1111/bjd.17980

22. Australian government department of health. Sunscreens: information for consumers. https://www.tga.gov.au/node/1911

23. Merlino G, Herlyn M, Fisher DE, et al. The state of melanoma: challenges and opportunities. Pigment Cell Melanoma Res 2016;29(4):404-416.

https://doi.org/10.1111/pcmr.12475

\section{MELANOMA: RISK FACTORS AND PREVENTION}

Ž. Aukštakojytè, A. Pociūtè, V. Trinkūnienè

Keywords: melanoma, UVA, UVB, skin cancer.

Summary

Melanoma is an aggressive skin cancer with a high potency of spreading to regional lymph nodes and internal organs. If not treated timely melanoma might cause fatal outcomes. The total number of patients diagnosed with melanoma were 2128 in 2019 in Lithuania. In order to prevent new cases of this oncological disease, it is necessary to know the risk factors and ways to reduce the chance of getting this skin cancer.

Aim. The purpose of this review was to examine the latest data on melanoma risk factors and its prevention measures.

Materials and Methods. Data search was performed in PubMed and Google Scholar. For the literature, keywords that correspond to the topic of our review were used. All included articles were published in English language and up to 5 years old.

Results. The risk factors of melanoma are UVA and UVB radiation, genetic predisposition (positive family history of melanoma and new mutations), phenotypic features (such as red hair or very light skin color), numerous and atypical moles. The higher risk of melanoma is related with immunosuppressive conditions and older age (patients $>50$ years old). To reduce the prevalence of melanoma, it is necessary to avoid sunburn and not to use artificial tanning devices. It is recommended to promote the use of measures against ultraviolet radiation: moisturizers with SPF filter, hats with wide edges and sunglasses. If possible it is recommended to avoid being outside in hours when the sun is more harmful. It is important to observe the new changes of your skin and assess possible changes of old moles. If any changes are noticed, it is necessary to visit a general practitioner. The doctor must perform a primary examination and if pigment lesions are observed would refer to a dermatovenerologist as soon as possible.

Conclusions. The main risk factors of melanoma are UVA and UVB radiation but melanoma can also be related to other factors (genetic predisposition, phenotypic features or immunosuppressive conditions). Public education is needed to increase consciousness of community due to melanoma. Primary care settings must be aware and higher usage of protective equipment against ultraviolet radiation are needed to reduce the risk of melanoma.

Correspondence to: zivile.aukstakojyte@gmail.com 